\title{
STUDY OF THE PERFORMANCE OF AIR CONDITIONING SYSTEM INCORPORATING CHILLED WATER STORAGE
}

\author{
A.S. Ali ${ }^{a}$, I.M. Ismail ${ }^{b}$ and M.S. Ahmed ${ }^{c}$ \\ a. Grad. Student, Mech. Engineering Dept., Faculty of Engineering, \\ Assiut University, Assiut, Egypt \\ b. Professor, Mech. Engineering Dept., Faculty of Engineering, Assiut \\ University, Assiut, Egypt. \\ c. Ph.D., Mech. Engineering Dept., Faculty of Industrial Edu., Sohag \\ University, Sohag, Egypt.
}

\section{(Received July 26, 2011 Accepted October 2, 2011)}

In the present study, an air conditioning system with a storage tank was constructed and tested. Along the 24 hrs, eight tank-charge cycles were performed to evaluate the effect of variation local ambient temperature on the system performance. A significant variation in the values of COP due to variation in local ambient temperature in Sohag city was recorded. There are two modes of chilled water storage, full-storage and partialstorage. This study deals with partial-storage mode. In this study, a comparison has been carried out between air conditioning system without chilled water storage and that with storage. Configuration of storage tank has a significant effect on system performance. Two storage tanks with aspect ratio of 1.1 and 2.2 were tested. A COP of 1.63 was achieved for the adopted system for no-storage mode. In partial-storage mode, the COP achieved was 1.73 in case of storage tank with aspect ratio 1.1, and 1.79 with aspect ratio 2.2 .

\begin{tabular}{|clcl|}
\hline \multicolumn{3}{c|}{ NOMENCLATURE } \\
$\mathrm{C}_{\mathrm{p}}$ & Water specific heat, $\mathrm{kJ} / \mathrm{kg}^{\circ} \mathrm{C}$ & $Q_{s}$ & Stored cooling capacity, $\mathrm{kJ}$ \\
$\mathrm{COP}$ & Coefficient of performance & $W$ & Energy consumption, kWh \\
$m$ & Mass of water layer in storage & $\Delta t$ & Temperature difference taking \\
& tank, Kg & & place in the layer, C \\
$Q$ & Cooling energy, $\mathrm{kWh}$ & $\rho_{w}$ & Water density, $\mathrm{kg} / \mathrm{m}^{3}$ \\
\hline
\end{tabular}

\section{INTRODUCTION}

A large proportion of the annual peak electricity demand, in commercial and office buildings, goes to satisfying the air conditioning load [1,2]. Most air conditioning systems in commercial and office buildings are operated at the day-time and contribute to the day-time demand peak. The cooling demand at peak is greatly larger than the daily average load. Chilled water storage (CWS) is a way to supply the cooling capacity required by a building while shifting electric utility demand and energy use from on-peak to off-peak hours. Besides shaving the peak load, CWS has many other benefits. As off-peak period is much longer than peak period and chillers can run at full capacity during charging the storage tank, CWS air-cooling system requires smaller 
capacity chiller. Often, money saved by downsizing the chiller can offset the cost of adding storage tank [3]. As chillers run at night-time when outside temperature is lower than day-time, chiller cycle COP is higher [4]. By selecting chiller plant designed to meet average loads, it is practical to operate a system in a partial-storage mode $[5,6]$. The chilled water storage with conventional water chillers operates under the same conditions as conventional air conditioning systems [6].

\section{SYSTEM DESCRIPTION}

The major components of the test rig are: two storage tanks, water chiller (commercial condensing unit, heat exchanger) and commercial fan coil unit. The first tank (1000 liter) has aspect ratio of 1.1. It is made of two layers of plastic. It is $1.2 \mathrm{~m}$ high and $1.1 \mathrm{~m}$ in diameter. The tank contains four thermocouples distributed on the vertical axis. The tank is insulated with 2" layer thickness of glass wool. The second tank (1000 liter) has aspect ratio of 2.2. It is made of two layers of plastic. It is $1.76 \mathrm{~m}$ high and $0.85 \mathrm{~m}$ in diameter. The tank contains two vertical strings upon which thermocouples were fixed, one on the side-wall and the other on the axis of the tank. In each string eight thermocouples are distributed. The commercial condensing unit used is "Carrier" model $38 \mathrm{CCD} 32-\mathrm{H}$, cooling capacity $8.7 \mathrm{~kW}$ and the refrigerant $\mathrm{R}-22$. Water chiller is a concentric double tube heat exchanger. The flow of the two streams is counter flow. The water flows in the annular space and the refrigerant flows in the inner tube. Outside diameters for inner and outer pipes are $1 / 2$ " and 1 " respectively while their length is $5 \mathrm{~m}$. Commercial fan coil unit used is model (Miraco York) CW-4 and the cooling capacity $5.2 \mathrm{~kW}$.

\section{THE CHILLED WATER STORAGE SYSTEM}

In principle, the water is stored inside the tank in stratified layers for later use in meeting cooling needs. In this type of system, chilled water is usually stored at night in a storage tank, and during the day-time chilled water from the tank is circulated to load [7].

The operating cycle of a CWS system consists of two processes. A charge process in which thermal energy is removed from the storage medium using a refrigeration system and discharge process in which energy is removed from the load by the cold storage medium.

\subsection{The charging process}

Charging the system should occur overnight when the ambient temperature is moderate. The chiller and the pump P-2 are operated simultaneously to charge the tank. Referring to Fig.1, during the charging process, the control valves CV2 and CV3 are opened while control valves CV1, CV4, CV5 and CV6 are closed.

\subsection{The discharging process}

In partial-storage mode during the discharging process, the chiller, pump P-2 and pump $\mathrm{P}-1$ are operated simultaneously to meet the peak cooling duty. The control valves CV1, CV4, CV5 and CV6 should be opened while control valves CV2 and CV3 should be closed. 


\section{INSTRUMENTATION}

Thermocouples types-J were located at four levels on the vertical axis of the storage tank. Thermocouples were also fixed at inlet to and outlet from the chiller, inlet to and outlet from the fan coil unit. The ambient air temperature was also measured. Orifice meters were installed to measure the flow rate of water to the chiller, to the storage tank and to the fan coil unit. Digital Watt-meter was used to measure the power consumption of the condensing unit and the pumps.

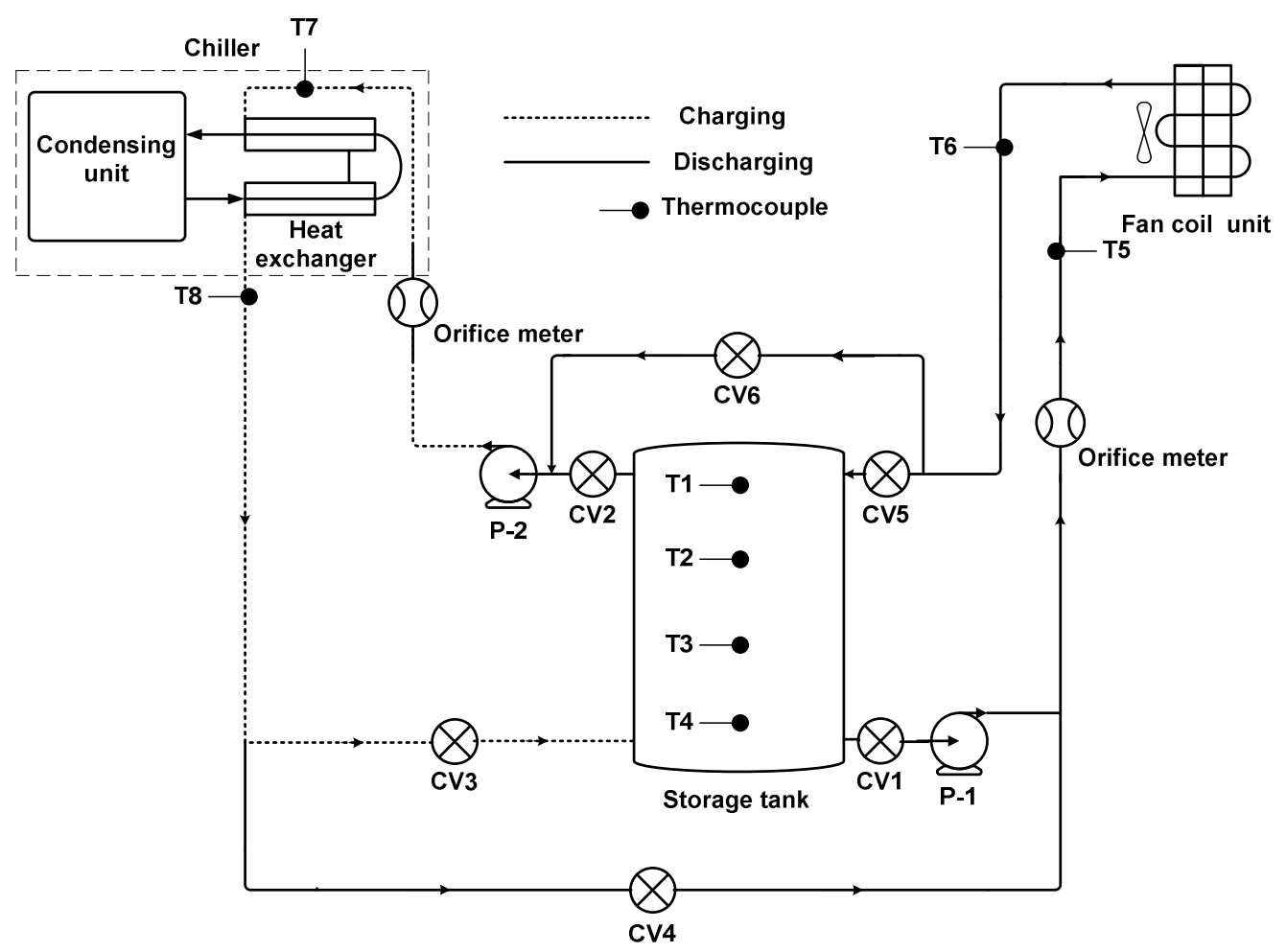

Fig. 1 Schematic diagram of a stratified CWS system

\section{SELECTING SUITABLE CHARGING AND DISCHARGING TIME}

Since the energy policy in Egypt does not reduce the $\mathrm{kW}$-hr price during off-peak period [8], the time at which the CWS has to be charged / discharged is not a parameter. The selection of the charging and discharging period has to be based on the profiles of both cooling load of the building and the electricity power generation. The profile of the electricity power consumption in Egypt is shown in Fig. $2[8]$. 


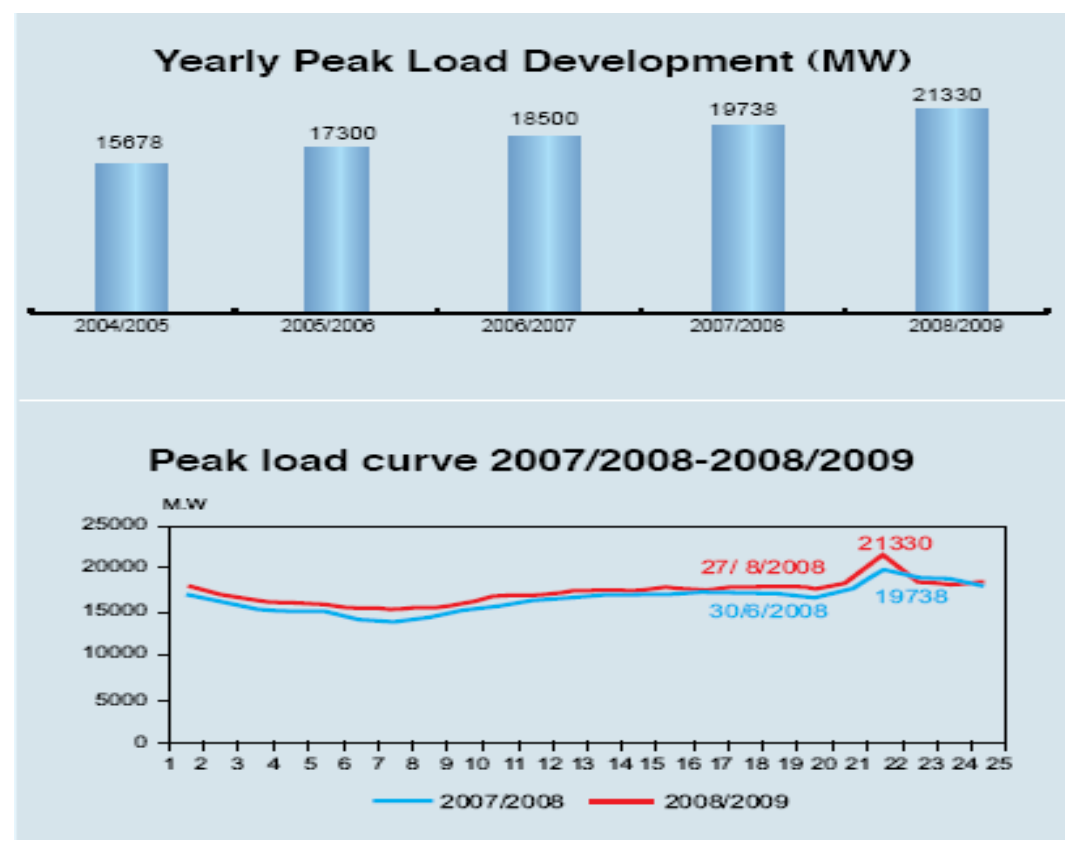

Fig. 2 Electricity power consumption in Egypt [8]

\section{RESULTS AND DISCUSSION}

The experimental work is divided into two important stages. The first stage is to evaluate cycle performance for eight tests along day time. The second stage involves conducting experiments applying no storage and partial-storage strategies. The performance evaluation of these strategies is presented here.

\subsection{Charging cycle performance along the $24 \mathrm{hrs}$ of the day}

Eight tests for charging cycle were performed on $7^{\text {th }}$ of august and the duration of each test was two hours. One hour was allowed before each test for preparation. During this hour, the stored water had to come to its initial condition. Thus, the temperature distribution in the tank was approximately the same at the beginning of the tests.

Figure 3 shows the temperature profiles inside storage tank (aspect ratio 1.1) for the eight experiments. It can be seen that the best stratification profiles were achieved during the period from 02:00 to 04:00, early morning, Fig. 3(g). On the other hand, less cooling of water in the tank was achieved during the period from 14:00 to 16:00, after noon Fig. 3(c). It is obvious that the lower the water temperature inside the storage tank, the larger the stored cooling capacity. 


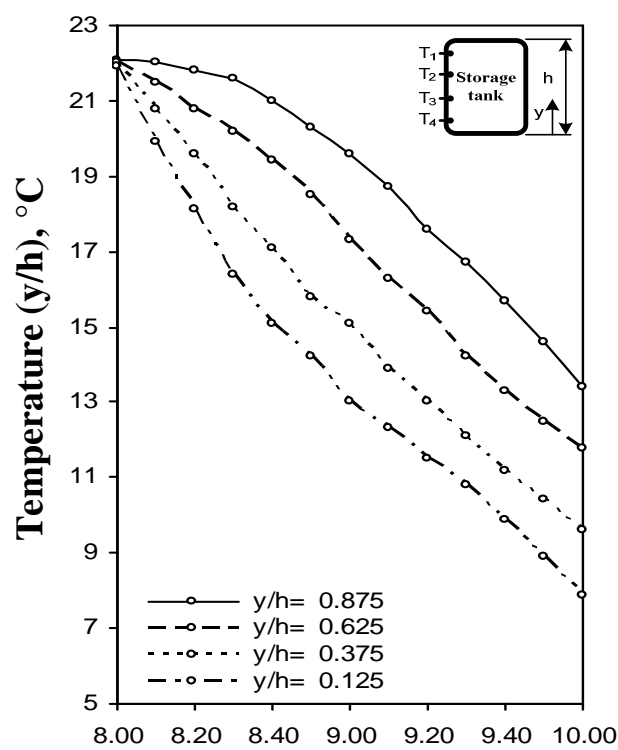

Time, hr

(a)

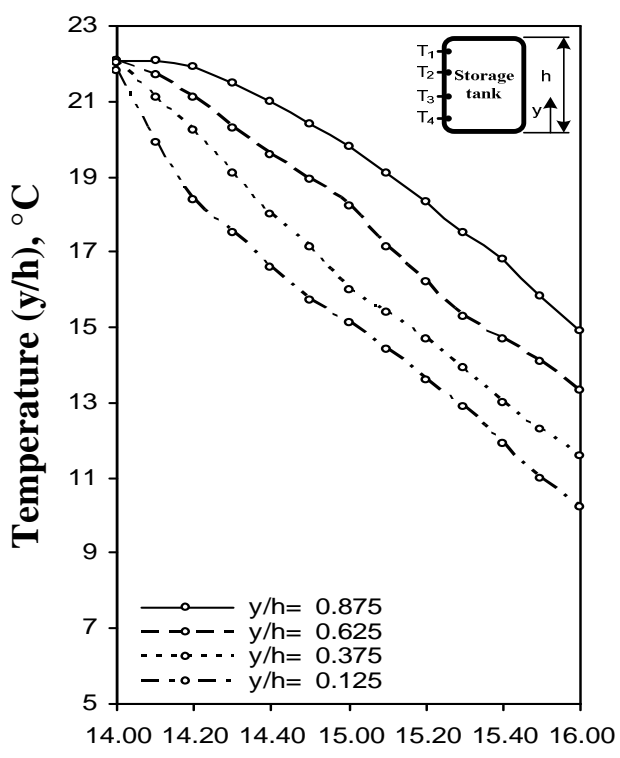

Time, hr

(c)

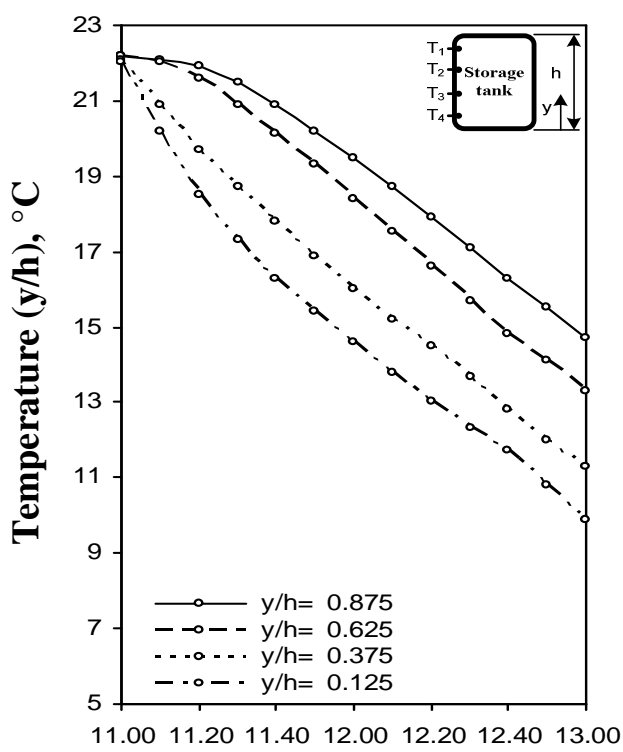

Time, hr

(b)

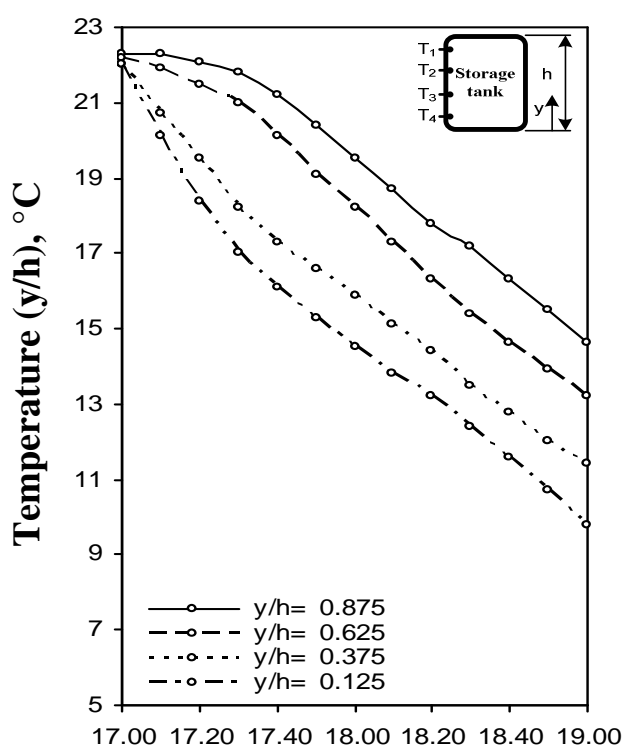

Time, hr

(d)

Fig. 3 Water temperature history at various levels inside chilled water storage tank (asnect ratio 1.1 ) 


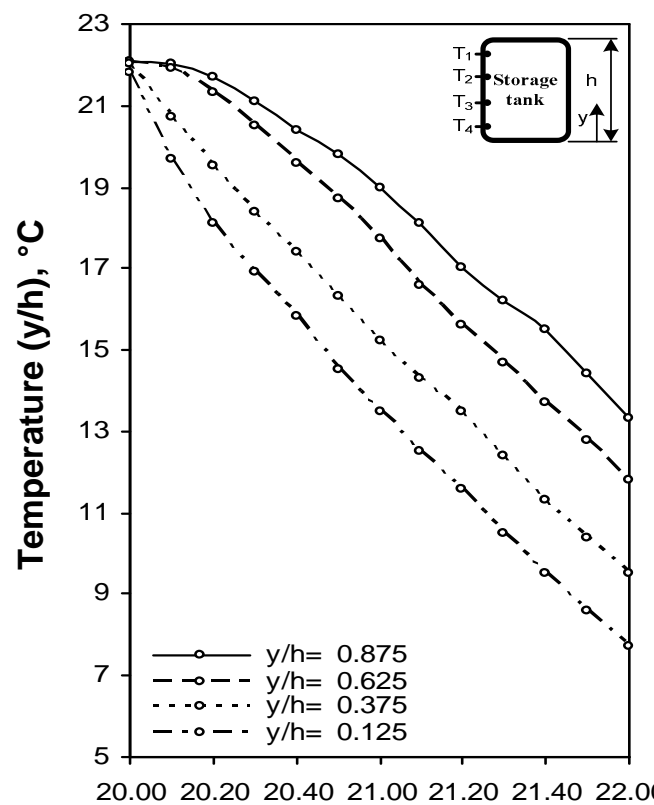

Time, hr

(e)

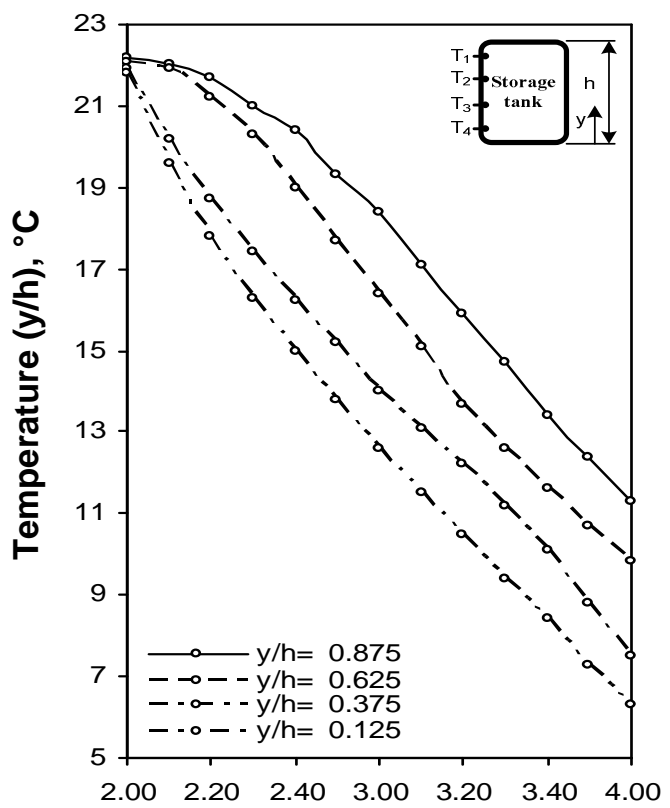

Time, hr

$(\mathrm{g})$

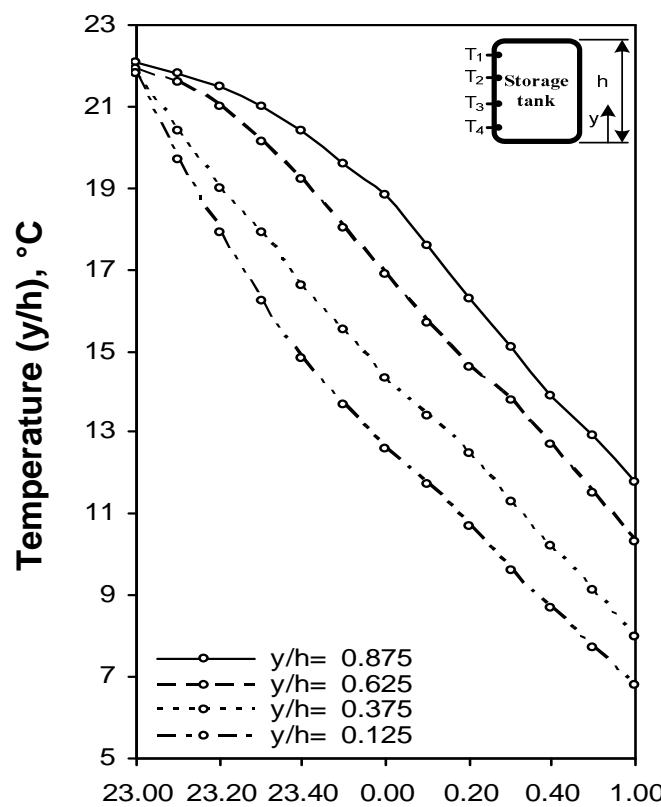

Time, hr

(f)

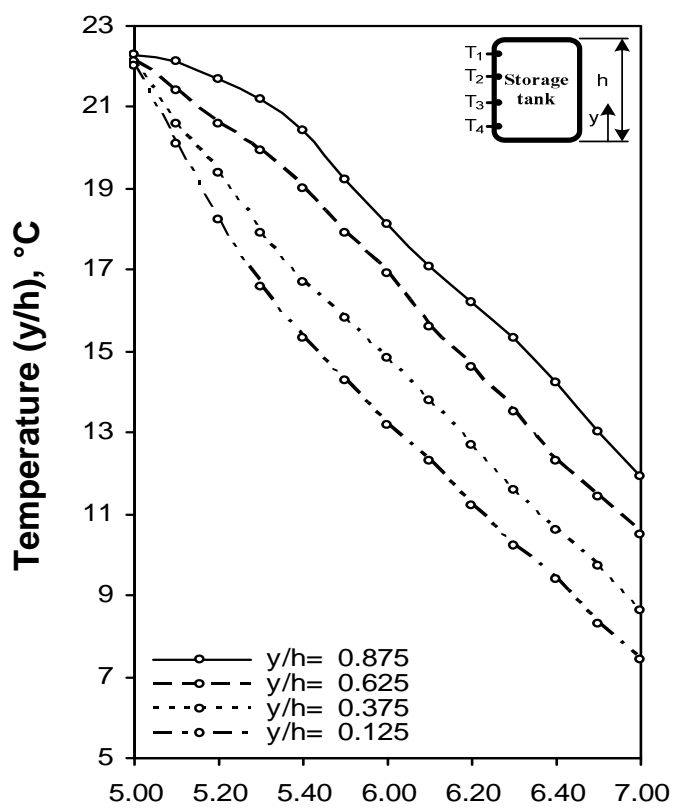

Time, hr

(h)

Fig. 3 Water temperature history at various levels inside chilled water storage tank (aspect ratio 1.1) 
As observed in Fig. 4, the large stored cooling capacity was achieved in the experiment running at the period from 02:00 to 04:00, whereas the minimum capacity was realized during the period from 14:00 to 16:00. The stored cooling capacity can be calculated by the following equation:

$$
\mathrm{Q}_{\mathrm{s}}=\sum m c_{p} \Delta t
$$

Where:

$Q_{s}=$ Stored cooling capacity, which is equal to the heat removed from the water in the tank, $\mathrm{kJ}$

$m=$ Mass of water layer in storage tank, $\mathrm{Kg}$

$c_{p}=$ Water specific heat at layer temperature, $\mathrm{kJ} / \mathrm{kg}^{\circ} \mathrm{C}$

$\Delta t=$ Temperature difference taking place in the layer, $\mathrm{C}$

Variations of density and $c_{p}$ with temperature were taken into consideration, given in appendix (A).

The value of COP is calculated using the following equation:

$$
C O P=\frac{\sum Q}{\sum W}
$$

Where:

$Q=$ Cooling energy, supplied by fan coil unit, $\mathrm{kWh}$

$W=$ Energy consumption, including condensing unit and pumps, $\mathrm{kWh}$

Figure 5 shows the values of COP calculated during the eight testes. It is clear that the value of COP is higher in case of low ambient temperature than in high ambient temperature. Figure 6 shows the variations of ambient air temperature on $7^{\text {th }}$ of august 2010 in Sohag city.

\subsection{Comparison between air conditioning without storage and CWS system}

The performances of no-storage and partial-storage modes were compared. The comparison has been carried out on the basis of measurements taken for two storage systems; the first has a tank with aspect ratio of 1.1 and the other with aspect ratio of 2.2 . 


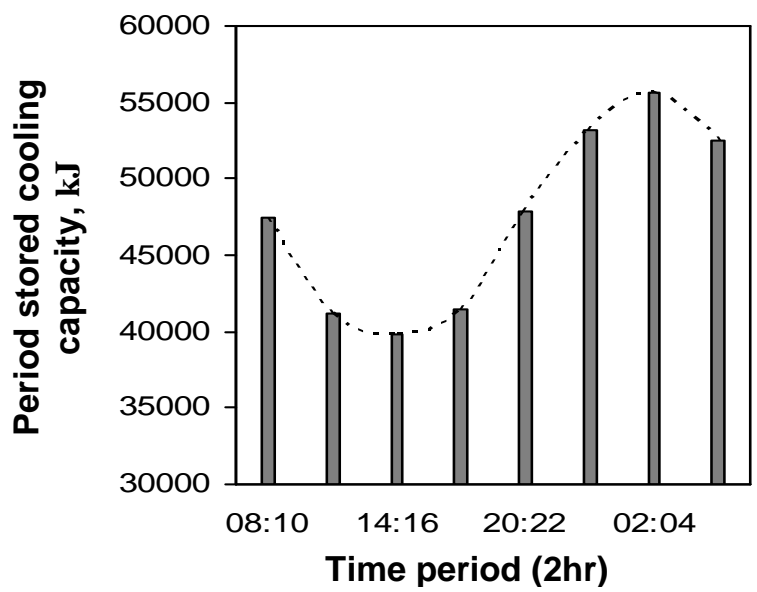

Fig. 4 Stored cooling capacity during eight periods

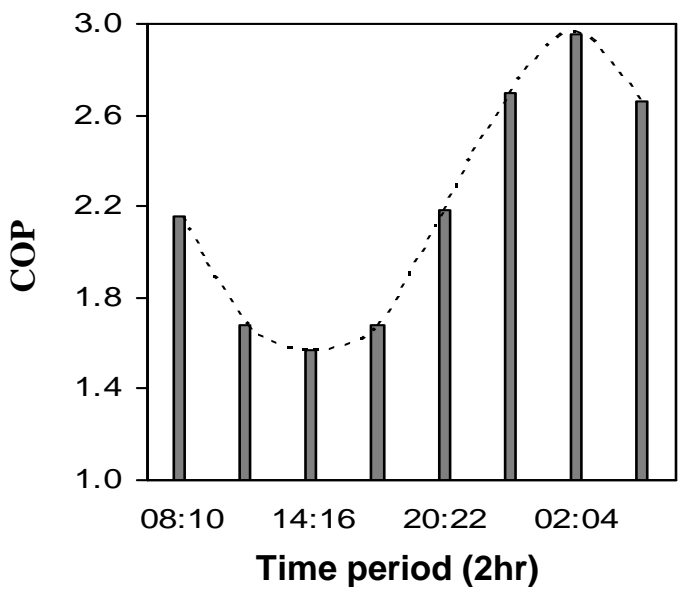

Fig. 5 COP during eight periods

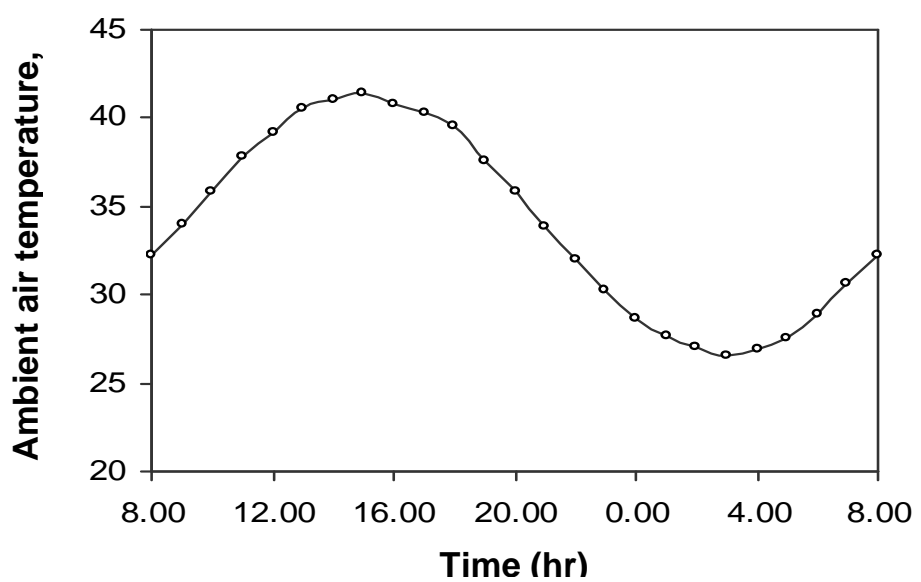

Fig. 6 Variations of ambient air temperature on $7^{\text {th }}$ of august 2010 in Sohag city 


\subsubsection{No-storage mode}

The air conditioning system without storage tank produces a cooling effect at the real time of the cooling is required. During peak cooling demands, chiller should have the capacity to cover these demands. The peak cooling demand is generally assumed to be from 13:00 to17:00 during which ambient air temperature is relatively high.

Table (1), in the appendix (B), gives the readings recorded during the peak load period with water flow rate $7.4 \mathrm{~L} / \mathrm{min}$. These readings include the rate of chiller power consumption, chilled water temperature inlet to and outlet from the chiller as well as chilled water temperature inlet to and outlet from the fan coil unit. The power consumption measured includes the power consumption of compressor; condenser fan and water pump P-2. Using these data, one can evaluate the following:

Energy consumed during the period $=14.32 \mathrm{kWh}$

Cooling capacity during the same period $=23.4 \mathrm{kWh}$

Hence:

COP for this period $=1.63$

\subsubsection{Partial-storage mode}

\section{a. Using storage tank with aspect ratio 1.1}

In partial storage mode, the storage tank meets a portion of the on-peak cooling load, while the rest met by the chiller. Table (2), in the appendix (B), gives the readings recorded during the charging period. These readings include the water temperature inlet to and outlet from the chiller and the rate of power consumed by the chiller.

The discharging process was four hours long. During this process, the chiller was run to meet a portion of the cooling load with water flow rate $7.2 \mathrm{~L} / \mathrm{min}$. Also in this period, the chilled water was withdrawn from the bottom of the tank at $7.4 \mathrm{~L} / \mathrm{min}$ and then supplied to meet the rest of the cooling load via the fan coil unit. Thus, the chilled water flow rate entering the fan coil unit was $14.6 \mathrm{~L} / \mathrm{min}$. Table (3), in the appendix (B), gives the readings recorded during the discharging period. These readings include the chilled water temperature inlet to and outlet from the fan coil unit and the rate of power consumption. The power consumption measured represents the rate of chiller power consumption and power consumption of chilled water pump P-1. Using these data, one can evaluate the following:

Energy consumed during charging period $=5.32 \mathrm{kWh}$

Energy consumed during discharging period $=13.28 \mathrm{kWh}$

Cooling capacity during the same period $=32.21 \mathrm{kWh}$

Hence:

COP for this period $=1.73$

\section{b. Using storage tank with aspect ratio 2.2}

Table (4), in the appendix (B), gives the readings recorded during the charging period. These readings include the water temperature inlet to and outlet from the chiller and the rate of power consumed by the chiller. 
Table (5), in the appendix (B), gives the readings recorded during the discharging period. The flow rate of chilled water outlet from the tank and the water passing in chiller were $4.3 \mathrm{~L} / \mathrm{min}$ and $7.4 \mathrm{~L} / \mathrm{min}$ respectively. These readings include the chilled water temperature inlet to and outlet from the fan coil unit, chilled water temperature outlet from the tank, chilled water temperature outlet from the chiller and the rate of power consumption. The power consumption measured represents the rate of chiller power consumption and power consumption of chilled water pump (P-1). Using these data, one can evaluate the following:

Energy consumed during charging period $=5.18 \mathrm{kWh}$

Energy consumed during discharging period $=15.09 \mathrm{kWh}$

Cooling capacity during the same period $=36.31 \mathrm{kWh}$

Hence:

COP for this period $=1.79$

\section{CHILLER COOLING RATE, POWER AND COP PROFILES FOR DIFFERENT OPERATING STRATEGIES}

In partial-storage the chiller operates at full capacity during the charging and discharging periods. During the charging process the chilled water is stored in the storage tank without covering the cooling load. The results of the cooling rate, power consumption, and the COP are analyzed in the following subsection.

\subsection{Chiller cooling rate}

The chiller in system without storage operates continuously throughout the four hours period to provide sufficient cooling to the load. In this period, the chiller runs at full capacity during the peak cooling demand period.

In partial-storage strategy, the chiller operates at full load during the discharging time from 13:00 to 17:00 when the building cooling load is directly met by the chiller and the storage tank. During the charging period, from 02:00 to 04:00, the chiller operates at full capacity to charge the storage tank. This system design is effective where the peak cooling load is much higher than the average load and also the lowest initial cost compared to other operating strategies $[9,10]$.

\subsection{Power consumption}

For the conventional system the maximum power demand occurs during the peak day. This is because of the higher ambient air temperature at peak day period.

In partial-storage strategy the chiller, during the night time, produces more cooling and consumes less power than during the day time. The degree of power reduction depends on the design operating strategy of the CWS system [11,12]. During discharging period the power consumption is similar to that of the no-storage mode as the capacity of the chiller for the two modes is the same.

\subsection{Coefficient of performance of the system}

The chiller with no-storage operation has a relatively lower COP during the peak period. It has been found that the COP during the peak period is about 1.63. COP is lower than that for the heat pump in which the evaporator cools directly the air, so the 
refrigerant evaporation temperature is higher than the existing case. Evaporator is used to cool water and so evaporation temperature is lower which results in a lower value of COP.

Stratification is one of the elements that may contribute in reducing the energy consumption and increasing the cooling capacity during charging process. Stratification also helped to benefit from the greatest part of the stored cooling capacity during discharging process. This resulted normally in increasing the COP. The experiments proved that the stratification improved markedly in storage tank with aspect ratio of 2.2 rather than the storage tank with aspect ratio of 1.1 .

Note that the load capacity covered by partial-storage mode is larger than the load capacity covered by no-storage mode. It has been found that the COP is equal to 1.73 by using a storage tank with aspect ratio of 1.1 , while COP is 1.79 with aspect ratio of 2.2 .

\section{CONCLUSION}

From this study, the following points could be concluded:

- A significant variation of the COP values was recorded due to variation in ambient temperature in Sohag city along the day hours.

- Using the storage tank with aspect ratio of 1.1 , the system COP increased by $6 \%$ compared to its value in no-storage mode, while it increased by $10 \%$ with storage tank of aspect ratio of 2.2.

- Noting that the load capacity covered by partial-storage mode is larger than the load capacity covered by no-storage mode.

- Stratification has a large effect on reducing the loss in stored cooling capacity. The experiments proved that the stratification improved markedly in storage tank with aspect ratio of 2.2 rather than the storage tank with aspect ratio of 1.1 .

\section{REFERENCES}

1. Gilani S.I., Majid M.A. and Rangkuti C., "Chillers Operating Strategies of Thermal Energy Storage Systems: Case Study of a Gas District Cooling Plant", International Conference on Energy and Environment, pp. 92-97, 2006.

2. Karim M.A., "Performance Evaluation of a Stratified Chilled Water Thermal Storage System", World Academy of Science, Engineering and Technology, Vol. 53, pp. 326-334, 2009.

3. Terry S., Eckerlin H. and Fang T., "Thermal Energy Storage: Analysis and Application", North Carolina State University, Master of Science, 2009.

4. Wang S.K., "Hand Book of Air Conditioning and Refrigeration", Second Edition, McGraw-Hill, 2001.

5. ASHRAE Handbook, HVAC Applications, 2007.

6. Boonnasa S. and Namrakai P., "The Chilled Water Storage Analysis for a University Building Cooling System”, Applied Thermal Engineering, Vol. 30, pp. 1396-1408, 2010. 
7. Ismail I.M., "Energy Conservation in Air Conditioning Systems by Using Storage Tanks", Bulletin of the Faculty of Engineering Assiut University, Vol. 22 No. 1, pp. 78-86, 1994.

8. http://WWW.egelec.com.

9. Sebzali M.J. and Robini P.A., "The Impact of Using Chilled Water Storage Systems on the Performance of Air Cooled Chillers in Kuwait", Energy and Buildings, Vol. 39, pp. 975-984, 2007.

10. Dincer I., "Thermal Energy Storage Systems and Applications in Buildings", Energy and Buildings, Vol. 34, pp. 337-388, 2002.

11. Sebzali M.J. and Robini P.A., "Analysis of Ice Cool Thermal Storage for a Clinic Building in Kuwait", Energy Conversion and Management, 2005

12. Hasnain S.M. and Alabbadi N.M., "Need for Thermal-Storage Air-Conditioning in Saudi Arabia", Applied Energy, Vol. 65, pp. 153-164, 2000.

13. Proprietes Physiques de Quelques Fluides Utilises Dans les Echangeurs de Chaleur Cetiat, Villeurbance, France.

\section{APPENDIX (A)}

A variation of water specific heat $\left(\mathrm{kJ} / \mathrm{kg}^{\circ} \mathrm{C}\right)$ with temperature is considered, using following formula [13]:

$$
c_{p}=A T^{3}+B T^{2}+C T+D
$$

Where $T$ is the water temperature $\left({ }^{\circ} \mathrm{C}\right)$ and the values of constants $\mathrm{A}, \mathrm{B}, \mathrm{C}$ and $\mathrm{D}$ are:

$$
\begin{gathered}
\mathrm{A}=0.749972 * 10^{-7} \quad \mathrm{~B}=-0.943717 * 10^{-5} \quad \mathrm{C}=0.448761 * 10^{-3} \quad \mathrm{D}=4.18674 \\
0.01<\mathrm{T}<270{ }^{\circ} \mathrm{C}
\end{gathered}
$$

A variation of water density $\left(\mathrm{kg} / \mathrm{m}^{3}\right)$ with temperature is considered, using following formula [13]:

$$
\rho_{w}=A T^{4}+B T^{3}+C T^{2}+D T+E
$$

Where $T$ is the water temperature $\left({ }^{\circ} \mathrm{C}\right)$ and the values of constants $\mathrm{A}, \mathrm{B}, \mathrm{C}, \mathrm{D}$ and $\mathrm{E}$ are:

$$
\begin{array}{lcl}
\mathrm{A}=-0.4879268 * 10^{-7} & \mathrm{~B}=0.27819864 * 10^{-4} \quad \mathrm{C}=-0.7525276 * 10^{-2} & \mathrm{D}=0.111546 \\
\mathrm{E}=999.085 & 0.01<\mathrm{T}<350{ }^{\circ} \mathrm{C}
\end{array}
$$




\section{APPENDIX (B)}

Table (1) Readings recorded for no-storage mode, average ambient temperature $40.8^{\circ} \mathrm{C}$

\begin{tabular}{|c|c|c|c|c|c|}
\hline \multirow{2}{*}{$\begin{array}{l}\text { Time } \\
\text { (hr) }\end{array}$} & \multicolumn{2}{|c|}{ Chiller } & \multicolumn{2}{|c|}{ Fan coil unit } & \multirow{2}{*}{$\begin{array}{c}\text { Chiller power } \\
\text { consumption } \\
(\mathbf{k W})\end{array}$} \\
\hline & $\begin{array}{c}\text { Water inlet } \\
\left({ }^{\circ} \mathrm{C}\right)\end{array}$ & $\begin{array}{c}\text { Water } \\
\text { outlet }\left({ }^{\circ} \mathbf{C}\right)\end{array}$ & $\begin{array}{c}\text { Water inlet } \\
\left({ }^{\circ} \mathrm{C}\right)\end{array}$ & $\begin{array}{c}\text { Water } \\
\text { outlet }\left({ }^{\circ} \mathbf{C}\right)\end{array}$ & \\
\hline 13.00 & - & - & - & - & - \\
\hline 13.10 & 16.3 & 4.6 & 4.7 & 16.2 & 3.55 \\
\hline 13.20 & 16.3 & 4.7 & 4.8 & 16.3 & 3.56 \\
\hline 13.30 & 16.5 & 4.8 & 4.9 & 16.4 & 3.56 \\
\hline 13.40 & 16.4 & 4.9 & 5.1 & 16.4 & 3.57 \\
\hline 13.50 & 16.4 & 4.9 & 5.0 & 16.4 & 3.58 \\
\hline 14.00 & 16.6 & 5.0 & 5.1 & 16.5 & 3.59 \\
\hline 14.10 & 16.5 & 5.1 & 5.2 & 16.5 & 3.59 \\
\hline 14.20 & 16.7 & 5.3 & 5.4 & 16.7 & 3.58 \\
\hline 14.30 & 16.9 & 5.4 & 5.5 & 16.8 & 3.59 \\
\hline 14.40 & 17.1 & 5.6 & 5.7 & 17.0 & 3.60 \\
\hline 14.50 & 17.2 & 6.0 & 6.0 & 17.2 & 3.60 \\
\hline 15.00 & 17.3 & 6.4 & 6.4 & 17.3 & 3.60 \\
\hline 15.10 & 17.2 & 6.3 & 6.3 & 17.2 & 3.60 \\
\hline 15.20 & 17.3 & 6.0 & 6.0 & 17.2 & 3.60 \\
\hline 15.30 & 17 & 5.6 & 5.7 & 16.9 & 3.59 \\
\hline 15.40 & 16.8 & 5.4 & 5.5 & 16.8 & 3.59 \\
\hline 15.50 & 16.7 & 5.3 & 5.4 & 16.7 & 3.59 \\
\hline 16.00 & 16.6 & 5.2 & 5.3 & 16.6 & 3.59 \\
\hline 16.10 & 16.6 & 5.0 & 5.0 & 16.5 & 3.59 \\
\hline 16.20 & 16.5 & 5.0 & 5.1 & 16.5 & 3.58 \\
\hline 16.30 & 16.5 & 5.0 & 5.1 & 16.5 & 3.57 \\
\hline 16.40 & 16.5 & 4.8 & 5.0 & 16.4 & 3.56 \\
\hline 16.50 & 16.4 & 4.8 & 5.0 & 16.4 & 3.55 \\
\hline 17.00 & 16.3 & 4.7 & 4.9 & 16.3 & 3.53 \\
\hline
\end{tabular}


Table (2) Readings recorded during charging process in partial-storage mode (aspect ratio 1.1), average ambient temperature $26.9^{\circ} \mathrm{C}$

\begin{tabular}{|c|c|c|c|c|c|}
\hline \multirow{2}{*}{$\begin{array}{c}\text { Time } \\
(\mathbf{h r})\end{array}$} & \multicolumn{2}{|c|}{ Chiller } & \multicolumn{2}{c|}{ Storage tank } & $\begin{array}{c}\text { Chiller power } \\
\text { consumption } \\
(\mathbf{k W})\end{array}$ \\
\cline { 2 - 5 } & $\begin{array}{c}\text { Water } \\
\text { inlet }\left({ }^{\circ} \mathbf{C}\right)\end{array}$ & $\begin{array}{c}\text { Water } \\
\text { outlet }\left({ }^{\circ} \mathbf{C}\right)\end{array}$ & $\begin{array}{c}\text { Water } \\
\text { inlet }\left({ }^{\circ} \mathbf{C}\right)\end{array}$ & $\begin{array}{c}\text { Water } \\
\text { outlet }\left({ }^{\circ} \mathbf{C}\right)\end{array}$ & - \\
\hline 2.00 & - & - & - & - & 2.67 \\
\hline 2.10 & 21.9 & 11.6 & 11.7 & 21.9 & 2.67 \\
\hline 2.20 & 21.7 & 11.3 & 11.3 & 21.7 & 2.66 \\
\hline 2.30 & 21.3 & 10.6 & 10.7 & 21.3 & 2.65 \\
\hline 2.40 & 21.1 & 10.3 & 10.4 & 21.1 & 2.64 \\
\hline 2.50 & 19.7 & 8.8 & 8.9 & 19.6 & 2.64 \\
\hline 3.00 & 19.1 & 8.2 & 8.4 & 19.1 & 2.65 \\
\hline 3.10 & 18.3 & 7.5 & 7.5 & 18.3 & 2.65 \\
\hline 3.20 & 17.2 & 6.6 & 6.8 & 17.1 & 2.66 \\
\hline 3.30 & 15.9 & 5.5 & 5.6 & 15.8 & 2.67 \\
\hline 3.40 & 15.2 & 4.9 & 5.1 & 15.1 & 2.67 \\
\hline 3.50 & 14.0 & 3.6 & 3.8 & 14.0 & 2.69 \\
\hline 4.00 & 13.5 & 3.5 & 3.8 & 13.4 & \\
\hline
\end{tabular}


Table (3) Readings recorded during discharging process in partial-storage mode (aspect ratio 1.1), average ambient temperature $41^{\circ} \mathrm{C}$

\begin{tabular}{|c|c|c|c|c|}
\hline \multirow{2}{*}{$\begin{array}{c}\text { Time } \\
(\mathbf{h r})\end{array}$} & \multicolumn{2}{|c|}{ Fan coil unit } & \multicolumn{2}{c|}{ Power consumption } \\
\cline { 2 - 5 } & Water inlet $\left({ }^{\circ} \mathbf{C}\right)$ & Water outlet $\left({ }^{\circ} \mathbf{C}\right)$ & Chiller $(\mathbf{k W})$ & Pump (kW) \\
\hline 13.00 & - & - & - & - \\
\hline 13.10 & 5.1 & 14.7 & 3.53 & 0.23 \\
\hline 13.20 & 5.2 & 14.8 & 3.53 & 0.22 \\
\hline 13.30 & 5.4 & 14.9 & 3.54 & 0.21 \\
\hline 13.40 & 5.7 & 15.2 & 3.55 & 0.23 \\
\hline 13.50 & 6.0 & 15.3 & 3.56 & 0.22 \\
\hline 14.00 & 6.1 & 15.4 & 3.56 & 0.22 \\
\hline 14.10 & 6.3 & 15.6 & 3.58 & 0.21 \\
\hline 14.20 & 6.7 & 15.9 & 3.59 & 0.23 \\
\hline 14.30 & 7.0 & 16.2 & 3.59 & 0.24 \\
\hline 14.40 & 7.2 & 16.3 & 3.60 & 0.23 \\
\hline 14.50 & 7.6 & 16.6 & 3.61 & 0.22 \\
\hline 15.00 & 7.9 & 16.7 & 3.61 & 0.21 \\
\hline 15.10 & 8.2 & 17.0 & 3.60 & 0.20 \\
\hline 15.20 & 8.7 & 17.6 & 3.59 & 0.20 \\
\hline 15.30 & 9.0 & 17.8 & 3.59 & 0.22 \\
\hline 15.40 & 9.4 & 18.3 & 3.58 & 0.22 \\
\hline 15.50 & 9.7 & 18.4 & 3.58 & 0.23 \\
\hline 16.00 & 10.2 & 18.9 & 3.57 & 0.21 \\
\hline 16.10 & 10.6 & 19.2 & 3.57 & 0.23 \\
\hline 16.20 & 10.8 & 19.3 & 3.56 & 0.24 \\
\hline 16.30 & 11.1 & 19.3 & 3.55 & 0.23 \\
\hline & & & & \\
\hline & & & & \\
\hline
\end{tabular}


Table (4) Readings recorded during charging process in partial-storage mode (aspect ratio 2.2), average ambient temperature $26.7^{\circ} \mathrm{C}$

\begin{tabular}{|c|c|c|c|c|c|}
\hline \multirow{2}{*}{$\begin{array}{c}\text { Time } \\
(\mathbf{h r})\end{array}$} & \multicolumn{2}{|c|}{ Chiller } & \multicolumn{2}{c|}{ Storage tank } & $\begin{array}{c}\text { Chiller power } \\
\text { consumption } \\
(\mathbf{k W})\end{array}$ \\
\cline { 2 - 6 } & $\begin{array}{c}\text { Water } \\
\text { inlet }\left({ }^{\circ} \mathbf{C}\right)\end{array}$ & $\begin{array}{c}\text { Water } \\
\text { outlet }\left({ }^{\circ} \mathbf{C}\right)\end{array}$ & $\begin{array}{c}\text { Water } \\
\text { inlet }\left({ }^{\circ} \mathbf{C}\right)\end{array}$ & $\begin{array}{c}\text { Water } \\
\text { outlet }\left({ }^{\circ} \mathbf{C}\right)\end{array}$ & - \\
\hline 2.00 & - & - & - & - & 2.61 \\
\hline 2.10 & 19.9 & 13.3 & 13.3 & 19.9 & 2.61 \\
\hline 2.20 & 19.7 & 13.1 & 13.2 & 19.6 & 2.59 \\
\hline 2.30 & 19.5 & 12.9 & 12.9 & 19.5 & 2.58 \\
\hline 2.40 & 19.4 & 12.7 & 12.7 & 19.3 & 2.58 \\
\hline 2.50 & 18.4 & 11.6 & 11.7 & 18.4 & 2.57 \\
\hline 3.00 & 14.6 & 7.8 & 7.9 & 14.5 & 2.58 \\
\hline 3.10 & 13.4 & 6.6 & 6.8 & 13.4 & 2.58 \\
\hline 3.20 & 12.8 & 6.1 & 6.1 & 12.7 & 2.59 \\
\hline 3.30 & 12.2 & 5.5 & 5.7 & 12.1 & 2.59 \\
\hline 3.40 & 11.7 & 5.0 & 5.2 & 11.6 & 2.59 \\
\hline 3.50 & 11.2 & 4.5 & 4.7 & 11 & 2.6 \\
\hline 4.00 & 10.6 & 4.0 & 4.3 & 10.5 & \\
\hline
\end{tabular}


Table (5) Readings recorded during discharging process in partial-storage mode (aspect ratio 2.2), average ambient temperature $40.8{ }^{\circ} \mathrm{C}$

\begin{tabular}{|c|c|c|c|c|c|c|}
\hline \multirow{2}{*}{$\begin{array}{c}\text { Time } \\
\text { (hr) }\end{array}$} & \multicolumn{2}{|c|}{ Fan coil unit } & \multirow{2}{*}{$\begin{array}{c}\text { Water } \\
\text { outlet from } \\
\operatorname{tank}\left({ }^{\circ} \mathbf{C}\right)\end{array}$} & \multirow{2}{*}{$\begin{array}{c}\text { Water } \\
\text { outlet from } \\
\text { chiller }\left({ }^{\circ} \mathbf{C}\right)\end{array}$} & \multicolumn{2}{|c|}{$\begin{array}{c}\text { Power } \\
\text { consumption }\end{array}$} \\
\hline & $\begin{array}{c}\text { Water inlet } \\
\left({ }^{\circ} \mathrm{C}\right)\end{array}$ & $\begin{array}{c}\text { Water } \\
\text { outlet }\left({ }^{\circ} \mathrm{C}\right)\end{array}$ & & & $\begin{array}{c}\text { Chiller } \\
(\mathbf{k W})\end{array}$ & $\begin{array}{r}\text { Pump } \\
(\mathbf{k W})\end{array}$ \\
\hline 13.00 & - & - & - & - & - & - \\
\hline 13.10 & 4.7 & 16.5 & 4.5 & 4.7 & 3.52 & 0.20 \\
\hline 13.20 & 4.9 & 16.6 & 4.6 & 4.8 & 3.53 & 0.19 \\
\hline 13.30 & 4.8 & 16.5 & 4.6 & 4.8 & 3.53 & 0.20 \\
\hline 13.40 & 4.9 & 16.5 & 4.6 & 4.9 & 3.54 & 0.19 \\
\hline 13.50 & 4.9 & 16.4 & 4.6 & 4.9 & 3.56 & 0.20 \\
\hline 14.00 & 5.0 & 16.5 & 4.7 & 5.0 & 3.57 & 0.20 \\
\hline 14.10 & 5.1 & 16.5 & 4.7 & 5.2 & 3.57 & 0.19 \\
\hline 14.20 & 5.2 & 16.4 & 4.8 & 5.2 & 3.59 & 0.19 \\
\hline 14.30 & 5.2 & 16.3 & 4.8 & 5.2 & 3.59 & 0.20 \\
\hline 14.40 & 5.2 & 16.3 & 4.9 & 5.3 & 3.61 & 0.20 \\
\hline 14.50 & 5.4 & 16.5 & 4.9 & 5.5 & 3.61 & 0.19 \\
\hline 15.00 & 5.6 & 16.6 & 5.1 & 5.7 & 3.60 & 0.20 \\
\hline 15.10 & 5.8 & 16.8 & 5.2 & 6.0 & 3.60 & 0.21 \\
\hline 15.20 & 5.8 & 16.8 & 5.5 & 5.8 & 3.60 & 0.21 \\
\hline 15.30 & 5.9 & 16.8 & 5.9 & 5.8 & 3.60 & 0.20 \\
\hline 15.40 & 5.9 & 16.8 & 6.1 & 5.6 & 3.58 & 0.19 \\
\hline 15.50 & 6.2 & 17.0 & 6.4 & 5.8 & 3.58 & 0.20 \\
\hline 16.00 & 6.8 & 17.6 & 6.9 & 6.4 & 3.58 & 0.21 \\
\hline 16.10 & 7.4 & 18.2 & 7.2 & 7.1 & 3.57 & 0.21 \\
\hline 16.20 & 8.0 & 18.9 & 8.0 & 7.8 & 3.56 & 0.22 \\
\hline 16.30 & 8.4 & 19.1 & 9.0 & 7.8 & 3.56 & 0.21 \\
\hline 16.40 & 8.5 & 19.2 & 9.2 & 7.9 & 3.54 & 0.22 \\
\hline 16.50 & 8.8 & 19.6 & 10.1 & 7.9 & 3.54 & 0.23 \\
\hline 17.00 & 9.1 & 19.7 & 11.0 & 7.9 & 3.53 & 0.22 \\
\hline
\end{tabular}




\section{"دراسة اداء منظومة تكييف هواء مع استخدام خزان المياه المثلجة"}

تم إنشاء واختبار منظومة تكييف هواء مع استخدام خزان مياه متلجة و تم عمل 8 دورات شحن للخزان

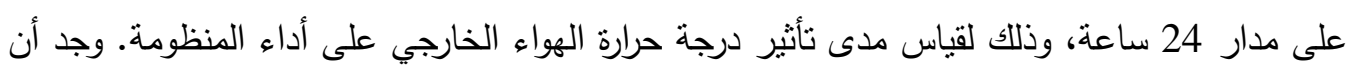

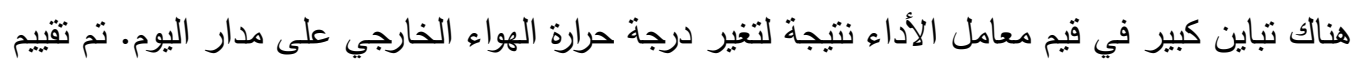

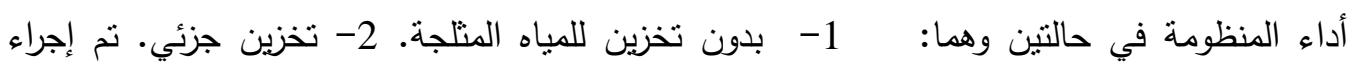

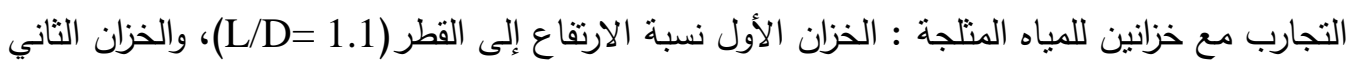

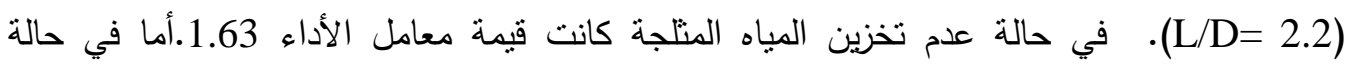

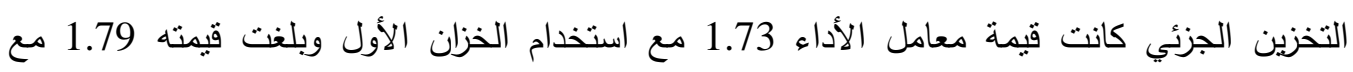
استخدام الخزان الثاني. 